\title{
Exploration of Practice Teaching Reform of Software Engineering Major Based on School- Enterprise Cooperation
}

\author{
Zhengliang Huan \\ School of Information Science and Technology \\ Taishan University \\ Taian, Shandong \\ hz18330016@163.com
}

\begin{abstract}
Practice teaching is an indispensable part of teaching procedure, which is the main channel to cultivate student's innovative and practical ability. In this paper, we take software engineering major of Taishan University as an example, which is based on model of school-enterprise cooperation, to explore and reform the practice teaching system, all kinds of links in this system, and operational mechanism. The purpose of all these things is to improve the teaching quality.
\end{abstract}

\section{Keywords-Practice teaching; Software engineering; Operational mechanism}

\section{INTRODUCTION}

The software engineering major of Taishan University, which was established in 2003, has been working with Shandong Shichuang Software Engineering co., ltd. in the construction of software engineering major since 2010. This major became the first batch of undergraduate comprehensive reform pilot major of the Ministry of Education in $2013^{[1]}$. We have found a series of problems in the procedure of university-enterprise cooperation, and we have also accumulated some experiences so far. For example, we take advantage of enterprise in practice teaching to practice and training, and we have established a practice teaching case base for personal and team ${ }^{[2]}$. We have built an on-campus training laboratory and a state-level off-campus practice teaching base ${ }^{[3]}$. After several years of cooperation between university and enterprise, the quality of talent training has improved significantly. We also summarized the existing problems in the practice teaching of software engineering: (1) We lack a complete practice teaching system, especially procedure management and assessment mechanism of practice teaching. (2) We did not pay more attention to the cultivation of engineering ideas, and we did not make good use of advanced practice management platform to track and manage student practice projects. (3) Most of the teachers who are working on practical teaching have not the software engineering background and practical project development experience. All these problems result in a series of problems, most of students can not integrate the project development requirements with their theory knowledge, students can not better understand the software development procedure, students have not opportunity to participate in the development of actual engineering projects. When the students to take an actual job, it is difficult to quickly integrate into the development environment ${ }^{[4][5]}$. It affects the quality of talent training and the employability.

\section{PRACTICE TEACHING REFORM MEASUREMENT}

\section{A. Establish a hierarchical practical training and teaching system.}

In the process of talent cultivation, we should pay more attention to ability training, and build the system of practice teaching. In cultivating scheme, we should set the practice teaching module, join four years practice teaching in together, sum up the experiences of university-enterprise cooperation through the study of the experimental teaching method. We should also cultivate the students' application ability by course experiment, course design, technical training, professional 
practice, and graduation designing, etc. For this reason, the practice teaching system of Multilevel, Open and Project (MOP) is constructed. According to the discipline foundation skill, professional basic skill, professional comprehensive skill and engineering practice ability to division level, adopt the in-class experiment, comprehensive practice, curriculum design, open project, research innovation project, subject professional contest and other forms of internal and external combination, for different student objects, based on the experimental teaching system to implementation of the layered and classification of refined culture. The four basic methods of task driving, problem driving, case driving and project driving are adopted to meet the requirement of different experimental courses and implement diversified experimental teaching methods. In the course of practice teaching, we should highlight the students' subjectivity, exert their subjective initiative and cultivate students' innovative spirit.

\section{B. Take advantages of enterprises, strengthen and improve the practice training.}

The professional ability is formed through repeated training in the use of intelligence, knowledge and skills. Therefore, we should set up enterprise training to improve the students' ability of software test, software implementation, software analysis and design, comprehensive ability. For example, enterprise training program of software test technology and skills as shown in table 1. The arrangement must follows the principle is that there is depth shallow, and it is from single to comprehensive. In addition, in the various stages of enterprise training, the evaluation is set up and the students can be evaluated according to the skills of the corresponding post. Put students in the environment of real enterprise scene, management system, competitive pressure, team collaboration, etc., to cultivate students' ability of software development, team cooperation and project management.

TABLE I. ENTERPRISE TRAINING SCHEDULE

\begin{tabular}{|l|l|l|l|}
\hline \multicolumn{1}{|c|}{ Name } & \multicolumn{1}{|c|}{ Time } & \multicolumn{1}{c|}{ Tontent } \\
\hline $\begin{array}{l}\text { Training 1 } \\
\text { Software test training }\end{array}$ & $\begin{array}{l}\text { Summer } \\
\text { vacation of the } \\
\text { second year. }\end{array}$ & $\begin{array}{l}\text { Test case development; software } \\
\text { performance test; software } \\
\text { functional software } \\
\text { development documentation. }\end{array}$ & $\begin{array}{l}\text { Develop students software testing capability and } \\
\text { develop a clear understanding of the engineering } \\
\text { development process of software. }\end{array}$ \\
\hline $\begin{array}{l}\text { Training 2 } \\
\text { Software development } \\
\text { training }\end{array}$ & $\begin{array}{l}\text { Summer } \\
\text { vacation of the } \\
\text { third year }\end{array}$ & $\begin{array}{l}\text { Web front-end page design; } \\
\text { Application of popular enterprise } \\
\text { framework; system architecture } \\
\text { design; system deployment } \\
\text { implementation. }\end{array}$ & $\begin{array}{l}\text { Strengthen the realization ability, analysis and } \\
\text { in specific software development areas. }\end{array}$ \\
\hline $\begin{array}{l}\text { Training 3 } \\
\text { Software engineering } \\
\text { comprehensive training }\end{array}$ & $\begin{array}{l}\text { The } \\
\text { semester }\end{array}$ & $\begin{array}{l}\text { Development of Java direction } \\
\text { information system; Web system } \\
\text { development in.Net direction. }\end{array}$ & $\begin{array}{l}\text { Strengthen the comprehensive ability of student } \\
\text { professional knowledge; set students to master the } \\
\text { engineering process of enterprise information } \\
\text { system. }\end{array}$ \\
\hline $\begin{array}{l}\text { Training 4 } \\
\text { Internship }\end{array}$ & $\begin{array}{l}\text { The } \\
\text { semester }\end{array}$ & $\begin{array}{l}\text { Embedded engineers; Mobile client } \\
\text { engineer; Java engineer. }\end{array}$ & $\begin{array}{l}\text { Strengthen the engineering practice ability of } \\
\text { students in specific positions }\end{array}$ \\
\hline
\end{tabular}

In the stage of enterprise project practice, establishing a full-time enterprise internship system that spans half a year. We introduce the real development project into the teaching, and further develop the students' engineering ability and professional quality through the real enterprise atmosphere and development environment. We will deep the practice of enterprise training, invite senior software engineers at the end of each semester to enter the school, face majors in all directions, and carry out technical training based on the real project of the enterprise. At the end of each semester, we will invite senior software engineers from several enterprises to enter the school, which will be geared to students of all majors and directions, and carry out technical training based on the real project of the enterprise.

C. Establish an innovative education system to improve the students' innovative ability and comprehensive quality.

We set up a comprehensive quality curriculum and practice platform, which adopts the mode of $\mathrm{M}+\mathrm{N}$. M is optional course library for the whole school, and $\mathrm{N}$ provides the curriculum library for professional quality. And 8 credits must be completed. In order to normalize the innovation of science and technology, we integrate science and technology innovation activities into and out of the classroom. In the teaching, we need to train special qualities include two kinds of spirit( collaboration, dedication), 5 kinds of consciousness (engineering, specifications, innovation, and the user, quality), 
five kinds of ability,(understanding, modeling, design, innovation, communication). Besides, we set up the innovation education credits in the talent training scheme. Many activities can be credited to credits, such as students to participate in all kinds of competitions, publish papers about scientific and technological achievements, taking part in scientific research activities and so on. And students must get at least four credits of innovation education.

\section{Totally implement the dual tutor system of university and enterprises.}

We should improve the system of tutoring and make full use of teachers' guiding role. Starting from the first year, equip with a mentor for each student, and each instructor or higher professional title should guide more than 3 students. Starting from the third year, enterprise's teacher should intervene, and we begin the "double tutorial system" to guide the students' course learning, course contests, graduation thesis, life planning, and guide students to declare technical innovation project, the research in the enterprise, participate in mentor's research topic and so on. Through the "double tutorial system", the student knowledge, technology, employment, life and other more comprehensive are guided fully, improving students' comprehensive quality.

\section{E. Establish the cooperative management mechanism of "resource sharing + responsibility sharing".}

It is important to establish the management system of open education to establish the cooperative management mechanism of school enterprise, in terms of the construction and sharing of talents, resources and information. It is clear the responsibility of the university and enterprises, to form a cooperative management mechanism for the sharing of resources and responsibilities. Thereby, the two sides make joint between colleges teaching quality and reform engineering breeding plan, practice teaching management rules and a series of throughout the practice. A scientific and complete evaluation system of students' practical ability and evaluation system of teachers' teaching ability are established teaching process management files, to ensure the smooth operation of the practice teaching. In order to do this, organizing Committee for practice teaching must be established. School-enterprise cooperation practice teaching organization committee is composed of school leadership and management, responsible for the organization and leadership, training standards, training target research. The Committee also includes teaching department of professional training, teaching technology, teaching quality assurance, teaching service, employment guarantee and so on.

\section{Conclusions}

Practice teaching is an important part of software engineering teaching system, playing an important role in cultivating the students' ability of autonomic learning, engineering practice ability, team cooperation, and communication ability. In order to overcome the deficiency existing in traditional practice teaching mode, the software engineering practice teaching is reformed and exploring the new experimental teaching mode. Practice shows that the new practical teaching model can stimulate students' learning enthusiasm and interest, improving the students' engineering practice and the team cooperation ability obviously.

\section{ACKNOWLEDGMENT}

Teaching reform research project of Shandong province in 2015 (262).

\section{REFERENCES}

[1] GUO Wei .Reform of Comprehensive Training on Software Engineering Based on CDIO [J]. Experiment Science and Technology, 2014, 12(5):115-117.

[2] WANG Wen-fa, WU Zhong-yuan, XU Chun. The Exploration and Practice of University-enterprise Cooperation Practice Teaching in Software Engineering Major in Local Universities[J]. Higher Education Of Sciences, 2016(2):114-119.

[3] KONG Yan-jie, GUO Ming-chao, MA Jun. The Design of Support Platform for Experimental Teaching Based on the Project and Case [J]. Higher Education Of Sciences, 2012, 102 (2): 114 -117.

[4] WANG Li-juan, LIU Rui-jie, HE Dan-dan. The Study and Application on the Reform of the Practice Teaching System of Software Engineering [J]. Value Engineering, 2013.06.105: 211-212.

[5] WANG Li-cai,LI Min,GAO Zhi-jian. Research of Practice Teaching System in Software Engineering Specialty [J]. Experiment Science and Technology, 2011, 9(6): 113-114. 